\title{
PEASANT SOCIETY IN JAPAN'S ECONOMIC DEVELOPMENT: WITH SPECIAL FOCUS ON RURAL LABOUR AND FINANCE MARKETS
}

\section{Masayuki Tanimoto}

\author{
University of Tokyo \\ E-mail tanimoto@e.u-tokyo.ac.jp
}

This study aims to discuss the significant role of "peasant society" in understanding the economic history of both modern and early modern Japan.

Independent peasant households proliferated in Japan in the seventeenth century, and from around the turn of the eighteenth century onwards they underwent a transformation into entities called ie, which owned family properties and bore responsibility for conveying these properties to the next generation. Although the development of the market economy also contributed to maintaining and activating the peasant society, the function of the labour market was strongly influenced by the strategy of peasant households to pursue the optimal utilization of slack labour generated by the seasonally fluctuating labour demand from agriculture. Under these constraints, peasant households tended to deliver non-agricultural employment opportunities to their members, forming a kind of barrier against mobilizing family workers outside the household. These barriers were supported by region-based industrial development such as a weaving industry adopting the putting-out system most suitable to the requirements of peasant households. Rural-based capital accumulation together with the workings of the regional financial markets contributed to maintaining particular peasant household behaviours by supporting region-based industrial development, which featured in Japan's path of economic and social development from the early modern to the modern period.

Keywords: peasant society; household economy; ie system; labour supply behaviour; putting-out system; rural-based capital accumulation; financial market; region-based industrial development

\section{INTRODUCTION}

It is well known that small farms run by family labour have dominated agriculture in East Asia, particularly in the case of rice cultivation. Farming households based on family workers can be referred to by the term "peasant", and previous discussions have already tried to understand the common features of early modern East Asian societies using the concepts of

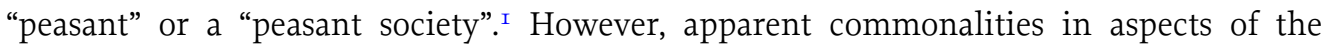


natural environment such as climate, or similar endowments of land, population, and agricultural technology, did not guarantee the uniform behaviour of peasant households across different societies. Institutions sometimes played a significant role in forming the particularities of each peasant society, and historical paths also influenced whether a society's particular features would be sustainable. The latter point requires us to widen our view beyond the early modern period, on which the above-mentioned discussions have tended to focus, in order to consider the economic functions of peasant society in an industrializing economy.

This study aims to discuss the significant role of "peasant society" in understanding the economic history of both modern and early modern Japan by focusing on the particular behaviour of peasant households and the functions of other economic agents in rural society. In doing so, we use the relationship between peasants and markets, specifically factor markets such as labour and capital, as a key to approaching these issues. The following points underlie this approach.

Although a peasant household can be self-sufficient in a historical setting, it is inappropriate to regard its nature as either self-sufficient or an element of a subsistence economy. Indeed, recent scholarship on the economic history of Tokugawa Japan has shown various evidence that both the growth of commercialized agriculture and the development of market-oriented non-agricultural industries occurred in rural areas from at least the latter half of the Tokugawa period onwards. ${ }^{2}$ These discussions reveal that various kinds of commodities, from consumption goods, such as food and cloth, to intermediate goods, exemplified by cotton or fertilizer, were sold and procured by peasant households. In this regard, it is possible to say that so-called Smithian growth based on the division of labour took place from at least the eighteenth century onwards among peasant-based societies in the Japanese archipelago. 3 Therefore, the simple notion of "the degree of marketization" can no longer be applied to measuring the workings of the peasant economy even in early modern Japan. However, it is worth noting that the development of the market economy mentioned above was mainly observed on the basis of volumes and variations of commodities exchanged and distributed in rural areas as well as in urban distributing centres. In contrast, aspects relevant to the factor markets, the labour and capital markets, have not explicitly been well explored in relation to discussion of peasant society. However, in general, the functions of factor markets seem to reflect the distinct features of participants' behaviour much more clearly than those of simple commodity markets do.

After confirming the institutional basis for peasant society by reviewing the process for establishing and developing this society from the seventeenth century onwards, this analysis provides several case studies discussing features of the labour market and the behaviour of peasant households, and then observes rural "industrialists" in the process of providing capital for the regional society. Through these discussions, this study aims to show in depth how the existing peasant society influenced Japan's path of economic and social development.

\footnotetext{
2 Hayami, Saitō and Toby, eds. 2004.
}

3 Mokyr I990; Saitō 2008. 


\section{HISTORICAL ORIGIN OF AND THE INSTITUTIONAL BASIS FOR THE PEASANT ECONOMY4}

The term "peasant" in both modern and early modern Japan implies a farming household based on family workers under a stem-family system. The standard peasant household comprised three generations of lineal family members, including a couple, namely, the head of the household and his wife, their children, and the parents of the head. The household maintained a certain area of arable land on its own account, either as owner or tenant. This unit of production and reproduction for maintaining the existing generation and creating and raising the next generation was widely established in the Japanese archipelago throughout the seventeenth century owing to specific historical conditions.

The comprehensive cadastral survey called kenchi 検地, initially executed by the Toyotomi administration in the late sixteenth century and recurring under the Tokugawa regime until the mid-seventeenth century, acknowledged the exclusive cultivation rights of a certain land area to a certain farming household unit in exchange for bearing the burden of nengu 年貢, which literally translates to “yearly tribute” in English. This survey was accompanied by the separation of peasants and warriors, who behaved as rulers of farming village workers. The former became the sole inhabitants of rural areas, and the latter were forced to move to castle towns newly developed by daimyos, the domain lords, and were deprived of direct access to the arable lands of their former residences. Edo, the substantial capital of the Tokugawa regime in addition to Kyoto where the emperor, Tenno, took up residence, can also be regarded as the largest castle town built by the Tokugawa shogunate.

However, this institutional setting did not automatically result in the proliferation of peasant households in the above-mentioned sense. Although these farming units established their positions independent of both rulers and other villagers, they may have exhibited diverse farming styles and family forms. In fact, large farms working arable land beyond the capacity that could be covered by family workers still existed, as did family units that were highly dependent on one head family that dominated the blood-related family group, lacking the autonomy to do their own farming. It took a century-long period to achieve a peasant society that consisted of independent small farms run by stem-family members.

The seventeenth century saw two distinctive socio-economic changes. The first was the great expansion of arable land. Estimates suggest that the arable land area increased from 2.06 million hectares at the turn of the seventeenth century to 2.97 million hectares in the early eighteenth century, an increase of more than 900,000 hectares within a century. This increase was driven by reclamation work executed mainly by the Tokugawa shogunate and domain lords intending to enhance their yearly tribute revenue, which was highly dependent on the volume of the agricultural harvest. The distinctiveness of this expansion is clear, as the increase in arable land area during the 50 years from the early eighteenth to the mid-nineteenth century was just around 200,000 hectares. The extensive exploitation of alluvial plains enabled this expansion, allowing the successful control of floods that had

4 The description in this section is based on the author's discussion in Sawai and Tanimoto 20I6, ch. I. Please consult this chapter for reference. 
prevented farmers from cultivating these potentially fertile lands. This technological knowledge originated in the mining industry that had flourished in the Japanese archipelago from the mid-sixteenth to the early seventeenth century. The progress of civil engineering technology together with the emancipation of the labour force from battlefields by the establishment of a unified government thus made this reclamation possible.

The second distinctive change was a shift in demography. Although the exceptionally high growth rate in the early modern period estimated by the historical demographer Akira Hayami, an increase from I 2 to 3 I million people from around the year I600 to the 1720 , has recently been downplayed when the initial population estimate was raised to 17 million, the fact remains that population growth during the seventeenth century was distinctive. The growth rate in this period stands in sharp contrast to that from the eighteenth to the early nineteenth century, in which the average rate of population increase was almost zero.

This concurrent expansion of arable land and population is reflected in the increasing number of villages, which also suggests an increasing number of farming households. In fact, some village-level documents show a reduction in the average size of farming households. Furthermore, a case study investigating a lawsuit record revealed that farming households moved to establish autonomy from the head family in terms of the treatment of family members or the inheritance of arable lands initially offered by the head family. Thus, it is clear that the population growth based on the physical expansion of agricultural lands resulted in the proliferation of small, independent farming units consisting solely of the lineal members of a stem family.

This shift was based on a specific mode of agricultural development. Since the rate of population growth exceeded that of arable land, the proliferation of farming units must have been accompanied by the enhancement of land productivity. The exploitation of relatively fertile lands in alluvial plains provided the initial condition, and the development of farming knowhow enabled sustainable enhancement. The intensive input of fertilizer, namely compost and grass manure in this period, was the foundation of this development, and the introduction and dissemination of an iron hoe called bitchūguwa 備中鍬 made deep cultivation easier using manpower, which enhanced the effects of fertilizer input. It is noteworthy that these shifts were accompanied by a reduction in the use of draught animals in farming. Akira Hayami regarded this reduction as a change in the preferred technology from plough to hoe, accompanied by a change in the preferred source of power from animal to human, and he famously conceptualized this move as an "industrious revolution". Although recent studies tend to attribute the decrease in the use of cattle to an infectious disease, rinderpest, and deny that it was an intentional choice by farmers, it is still important to recognize that the development of these farming techniques did not require investment in draught animals (capital). Rather, it required the intensive input of human labour for cultivation, fertilization, weeding, transport work, and so on to enhance agricultural productivity, leading to a labour-intensive method of agricultural development.

Regardless of the drivers of this shift, the new method of development was a good fit with the nature of peasant households, not only because it was applicable to households without capital but also, more importantly, because family workers were most adaptable to the requirements of intensive labour input. It is well understood that agricultural 
work entailed inherent difficulties in monitoring the correspondence between effort and results; results that sometimes manifested themselves only after the harvest and were often difficult to attribute to separate individual effort. Thus, requiring intensive labour input without heteronomous control necessitated the spontaneous commitment of workers. In this regard, independent family farms based on a stem-family system possessed the appropriate incentives to engage in highly labour-intensive agriculture and were able to take advantage of this method. Independence from a head family and from rulers guaranteed that households could claim the results corresponding to their labour input, and individual family members had incentives to be industrious as they held potential claims to the results of their labour. Better farming results could not only raise their current standard of living but might also increase the amount of inheritance property or broaden the scope for desirable marriage opportunities. This ability to align the current results of farming with their long-term interests seemed to encourage family members to spontaneously provide intensive labour input. This notion can somewhat be confirmed in contemporary writings. In the early eighteenth century, during the Kyōhō period, an agricultural book, Minkanseiyō 民間省要, stated that "the result of intensive work by a couple and their children is superior to that of landowning farmers." The book also mentioned that among landabundant farmers, those who cultivated their arable land using employees had inferior profits to those of farmers who lent their land to small tenants. Thus, the proliferation of peasant households was based on the superiority of their farming practices derived from a combination of labour-intensive agricultural techniques and the incentive structure embedded in a farming household consisting of a stem family system.

As the reclaimable frontier became exhausted at the turn of the eighteenth century, the growth in arable lands almost ceased. In tandem, population growth also stagnated, at least in the early eighteenth century. In addition, an important institutional change took place that determined the behaviour of peasant households: the diffusion of the single inheritance system. Given a fixed arable land area, peasant households adopted this system so as not to weaken their economic base by dividing their holdings into plots that were too small. In fact, this concern over dividing arable lands across rulers had already been expressed by an ordinance of the Tokugawa shogunate in 1673 that restricted the division of lands. This single inheritance practice that set the eldest son as sole successor, together with the dissemination of three generations of cohabitation, worked to fix the stem-family system in peasant households. Whereas non-successors, the younger sons, had to leave their home villages, the successors, the heads of peasant households, inherited their households' lands as family properties. Combined with the idea of ancestor worship, peasant households remaining in villages were thus transformed into entities called ie 家, which owned family properties, including cultivation rights and ancestor worship rights. The successors of these households, namely the current heads of $i$, bore responsibility for conveying these households' properties to the next generation. Necessarily, peasant households became more firmly attached to their home villages to prevent their ie from decline. The formation of a new peasant society throughout the seventeenth century was thus completed with the establishment of the ie system, a social institution, deeply embedded in these peasant households.

This newly established peasant society continued to dominate Japan's rural society until the twentieth century, across the institutional changes of the I870s after the Meiji 
Restoration. As Table I suggests, the number of farming households continued to be fixed at around 5 million from the late nineteenth century until the twentieth century. The distribution of the scale of farming shown in Table 2 was also almost unchanged until the twentieth century and stayed within the range of family farming despite the fact that the structure of land ownership had drastically broken down into one of landowners and landless tenants. In other words, peasant households still dominated the agrarian sphere and rural society up until the twentieth century in Japan. By showing a concise summary of case studies executed by the author, the next section describes the features of the labour market in which peasant households participated.

\section{HOW DID PEASANT HOUSEHOLDS PARTICIPATE IN THE LABOUR MARKET?}

First, let us look at a case showing an aspect of the labour market for agricultural work in the eighteenth century. The Asada 浅田 family, who resided in the Yamashiro region (the southern part of present-day Kyoto prefecture), managed around four hectares of arable land in the late eighteenth century, employing wage workers in addition to family members for cultivation. 5 Table 3 compiles the working days of workers that appeared in their Hiyōoboechō 日雇覚帳 (the record of daily employment) in I783. Gohei 五兵衛 and Seishichi 清七, employees engaged in the Asadas' farming, had distinct numbers of working days in this table. They were likely under specific labour contracts, since records of daily wage payments existed for only 3I out of 204 working days for Gohei and for almost no days for Seishichi, but this gap was not due to a lack of records. According to Table 4, Gohei worked for nineteen days in October with four days of daily wage payments. The payment dates exactly coincided with instances when Gohei worked more than two days continuously, and this regularity can be confirmed in other months as well. From this evidence, we assume that Gohei contracted with the Asadas to work fifteen days per month, with a pattern of two days working and two days off in turn. Daily wages were paid when Gohei worked outside this pattern. This contract seems to be an ideal combination of regularity and flexibility, since an employee under this contract could keep some of his working hours for other occupational opportunities, specifically for farming on his own account.

Flexibility in working days was much larger for employees other than Gohei and Seishichi in Table 3, whose working days totalled fewer than 12 days per month and fewer than 40 days per annum. However, this short-term employment did not imply that these employees were a floating labour force wandering about the countryside. For example, Kyūshiro, who worked 20 days intermittently over the period from the ist of January to the 8th of April, was paid his entire wages on the IIth of April. Yasuke's one day of work on the 2Ist of October was paid on the 26th of December. Thus, payment amounts were strictly counted by day, but payments were easily postponed. These facts suggest that even if employment was contracted on a temporary basis, the relationship between an employer and an employee was not necessarily transient. Indeed, it was by 
no means rare for the same day labourer to appear in Hiyō-oboechō year after year. Judging from place names, their residences were close to that of the Asadas.

From this case study, we can extract the following points that might suggest features of the agrarian labour market in rural society. I) Agricultural work tended to move from small family farms to large farms. 2) This exchange of labour was also mediated by a market mechanism that was exemplified by the existence of workers employed with daily wages. 3) However, the relationship between an employer and a worker was not particularly temporal despite the day-based labour contracts that tend to evoke an image of a fluid worker.

Second, let us consider the labour market from the perspective of farming households, potential providers of employees. Table 5 compiles survey data from a village, Udaōtsu 宇多大津, in Izumi region (the southern part of present-day Osaka Prefecture) in the I840s. ${ }^{6}$ This village is well known in the "proto-industrialization" literature of Japan as it included a large number of households engaged in an occupation related to the cotton spinning and weaving industry. Indeed, I89 households out of a total village of 279 households were engaged in farming. It is notable, however, that over 80 per cent of households were also engaged in non-agrarian occupations. One-third of households were not engaged in cultivation, but this was due to a lack of sufficient labour for family farms rather than making a choice to specialize in non-agrarian work. One-person households, often the households of widows, accounted for a high fraction of these non-cultivating households. A large percentage of households combined industrial work with the cultivation of tenanted land, land which was not of sufficient size to make use of all available family labour. This shortage of land did not lead to abandoning cultivation and specializing in non-agricultural occupations, but it did lead to the inclusion of non-agricultural activities in the portfolio of household work. Cotton-related activities, such as spinning and weaving, were suitable for this peasant household strategy. Table 5 indicates that households with small- and medium-sized cultivation areas of 0.1 to 0.2 hectares per person were more inclined to engage in cottonrelated work. As with other non-agricultural occupations, cotton processing was carried out in households that sought to attain full-time farming status.

This combination of industrial work and cultivation is also shown in Table 6, which tabulates data from I875 obtained from an industrial survey of Kitano village in Iruma 入間 district, one of the newly risen weaving districts adjacent to Tokyo prefecture. The turnout rates of weaving households in stratums classified by the value of agricultural production per household did not inversely correlate with the grain production output. Therefore, it is clear that the division of labour between agriculture and weaving did not lead to specialization among households. The production of striped cotton cloth in Iruma in the I870s was highly dependent on the weavers being embedded in peasant households, which is similar to the case of Udaōtsu in Izumi district in Table 5.

The embeddedness of non-agrarian work in peasant households can be confirmed more clearly by the following case, which also suggests the continuity of peasants' labour supply behaviour up to the turn of the twentieth century. Figure I shows the output figures (as indicated by the number of orders placed) and wages for the peasant-weavers subcontracted

6 The discussions on Udaōtsu village and Kitano village are based on Tanimoto I998, ch. 4 and ch. 2. See also Tanimoto 2009. 
by a prominent clothier of the Takizawa Kumakichi 滝沢熊吉 family in Iruma district. The remaining documents concerning the Takizawas' business activities, including various account books, enable us to analyse the transactions between the clothier and the peasantweavers.7 The data in Figure I suggests that there were significant seasonal fluctuations in the volume of output and the wages provided by the clothier. Although the subcontracted volume drastically fell during the period May to July, it increased during the periods March to April and September to January. However, the wages paid at piece rates decreased in the winter to the extent that the wage in January was less than half that in June. If the demand for weaving labour determined the wage, the wage level should have increased in the winter, which was one of the peak periods of production. Figure I, however, shows that the highest wage was paid in the slack period of production (i.e. in June). It follows that the labour demand in this region was influenced largely by factors other than those inherent to the weaving labour.

Specifically, in Iruma, the period from May to June coincided with the peak period of barley harvesting, tea making, and sericulture. During these months, female labour within a peasant-weaver household tended to be allocated to agriculture-related activities, which consequently reduced the available supply of labour for weaving. At the same time, this was a period when the clothier attempted to increase the volume of cloth. Since market competition positioned the fabrics of Iruma as winter clothing, the sale of fabric by the Takizawa family was heavily concentrated in autumn, as we can see from Figure I. Thus, for the clothier, it was desirable to increase production during this period in preparation for autumn sales. The high level of labour demand for weaving on the one hand and the seasonal shrinking of the labour supply on the other caused the relative hike in the wage rate during this period. Thus, within peasant households, we can assume that the supply of labour for wage weaving was determined in relation to the labour demand for agricultural activities.

This example proposes several points that might characterize the relationship between the non-agrarian labour market and peasant households. I) The occupational plurality of peasant households did not imply self-sufficiency but rather a strategy of utilizing the labour force endowed in a household. The distinct seasonality of the labour supply exemplifies this assumption. 2) The market mechanism in the industrial (weaving) labour market functioned rather well, judging from the profile of the wage fluctuation, which sensitively reflected changes in the demand and supply of the relevant labour. 3) However, the labour market for industrial work was not entirely dependent on industrial work itself, since the demand for agricultural work had a great influence on the supply of labour for weaving work.

These interpretations suggest that, although the market mechanism almost dominated the exchange process of labour, the labour supply itself was largely influenced by a particular behaviour of the units of labour supply, which were not individual people but peasant households as a whole. In the next section, we look into the internal structure of the peasant household.

The discussion on the peasant-weavers is based on Tanimoto 2006a. See Tanimoto I998, ch. 6 and ch. 7 for details of the activities of the Takizawa Kumakichi family. The term "peasant-weaver" implies that a worker who was engaged in weaving as a piece-weaver was included in the peasant household. 


\section{THE ORIGIN OF THE LABOUR SUPPLY BEHAVIOUR OF PEASANT HOUSEHOLDS}

How was agricultural work combined with industrial work? What determined the labour supply other than the demand for labour for production? An economic survey of farming households carried out in the early twentieth century provides us with information to approach these questions.

The first sample is a survey of a household in Izumi region in I90I, which preceded a full-fledged survey undertaken after World War I. Table 7 compiles figures on the allocation of tasks carried out among household members. ${ }^{8}$ The household head was fully occupied in agricultural production. To meet the labour demand for agriculture during the two peak periods, he had to also mobilize the labour of his wife and elderly mother. As a result, a limitation was placed on the amount of time his wife could allocate to weaving. This limitation is vividly illustrated by the fact that the amount of labour of both his wife and daughter allocated to weaving production is only the equivalent of $\mathrm{I} .5$ years in labour-days.

At the same time, it should be noted that there was a mechanism that served to increase the amount of labour devoted to weaving. Specifically, the labour of the household head's "old mother" relieved the burden of agricultural labour required of his daughter, which then enabled his daughter to devote all of her available labour (except for necessary housework) to weaving. Even in the case of housework, his "old mother" could cover the relatively heavy burden of "cooking" and reduce the labour demands of his wife and daughter. Moreover, his "old father", who was over seventy, was mobilized to participate in yarn reeling, and an eleven-year-old son was also assigned a portion of housework: babysitting. Thus, the members of the household least suitable for full-time labour in agriculture or industrial production, which includes both the elderly and any younger children, were assigned auxiliary tasks, including housework, so that more labour could increasingly be spared for weaving.

The second sample is from a peasant household located in Tottori prefecture on the Japan Sea coast. 9 The survey was carried out in I9I 8 and collected data on working hours. Judging from the fact that the head of the household was a member of the village assembly, this household could probably have been classified as that of an upper-class farmer in the village. However, its area of cultivation, around I cho (I hectare) of paddy land for rice and around 5 tan (0.5 hectare) of dry field for barley, was around the average level in this village, and its labour force was limited to the lineal family, as neither collateral family members nor employed workers were working that year. Therefore, this household was not a polar case, but represented some common features of an owner-farming household in that period.

Cultivation occupied more than 60 per cent of the household's total "working" hours, alongside other manufacturing work, such as tatami mat production. Table 8 shows the working hours of individual family members. The household head, his wife, and his father

8 The discussion on the household survey in Izumi region is based on Tanimoto I998, ch. 4. See also Tanimoto 2009.

9 The discussion of this sample is based on Tanimoto 2003. 
devoted more than three-quarters of their working hours to "production work", such as cultivation, and to "industrial work", such as manufacturing tatami mats or straw products, and cocoon breeding. These three members were apparently mainly engaged in income-earning work in a broad sense (hereafter referred to as "producing labour"). On the other hand, the household head's mother devoted more than eighty per cent of her hours to housework. The proportions of time spent by the household head's first daughter on producing labour and housework were 60 per cent and 40 per cent, respectively. The second daughter, who was a student at that time, devoted around I,000 hours to housework.

It is worth noting that female labour played a significant role in cultivation as well as in the other sideline work defined in this survey as "industrial work". In this sense, it is not appropriate to say that a clear gender division of labour existed in the field of labour production. However, it is also clear that housework (except firewood gathering) was mainly performed by women rather than by men. We can observe as well a division of labour in the field of housework among female members. In other words, the housework demands of this household were fulfilled by multiple female members, and the total housework hours $(6,854$ hours) recorded in the table far exceeded the annual working hours of a single person.

By observing the data extracted from these two surveys, we propose several points that might characterize the labour allocation strategy within peasant households. I) Agricultural work seemed to be the priority of adult male labour. 2) Female labour was allocated to both agricultural and industrial work according to the situation. 3) The premature and elderly workforces were utilized to complement the labour demand that was mainly fulfilled by members of the core workforce. These three points suggest that a household should be regarded as a unit of labour that strategically allocated agricultural and industrial tasks to each member to achieve its goals. Furthermore, note that housework occupied a significant portion of female labour in these two cases. Was housework allocated to the residual working time after work for income was complete, or did it positively influence the labour allocation strategy in the household?

The fact that the burden of housework was shared by multiple female household members, as clearly shown by the case above, is worth further examination. ${ }^{\text {Io }}$ We can confirm and generalize this finding by observing the data shown in the individual sheets of the Nōka Keizai Chōsa 農家経済調査 (Economic Survey of Farming Households) conducted by Kyoto Imperial University during the inter-war period.

The data set obtained from surveys of 44 different households conducted in I927, I928, and I93 I reveals that housework was carried out by 2.84 women and 2.30 men on average per household, that few men did more than I,ooo hours of housework per year, and that women performed 82.5 per cent of the total housework hours. Thus, it is clear that housework was disproportionately allocated to female household members and that each household had on average more than one female member performing housework. The average number of women engaged in more than I,O0o hours of housework per household (I.34) reveals that there was often more than one key person doing housework and that

Io The following discussion on housework is based on Tanimoto 20I2. Since a slight revision was conducted by Tanimoto 20I6, please refer to the latter paper regarding the results of the regression analysis. 
these individuals were additionally complemented by other women engaged in housework for a relatively lower number of hours. This observation seems to be consistent with the fact that several women were carrying out the housework in each household.

Regarding the attributes of household members engaged in housework, the data described above reveals that a household head's mother undertook housework at almost the same level as that of the household head's wife. It is also noticeable that the maximum number of housework hours was fewer than I,6oo. Thus, if we take into account the annual total working hours of the individual household members, not even the household head's wife can be recognized as a full-time housewife, but the total housework hours per household reached approximately 4,000, which is almost equivalent to the full-time working hours of one person. Thus, women in farming households combined housework with other tasks while together fulfilling housework demands equivalent to those carried out by a full-time housewife.

The discussion thus far reveals that the supply of housework was related to the presence of female household members. We now need to observe the demand side of housework and consider how demand and supply determined the level of housekeeping in farming households. To confirm the possible influence of each factor on housework hours, we therefore need to conduct a multiple regression analysis. The annual housework hours per household is set as the dependent variable and is regressed on various explanatory variables, such as family composition, household expenses, and household income level. Table 9 is a concise summary of the results using the data set in the Nōka Keizai Chōsa (Economic Survey of Farming Households) conducted by Nörinshō, the Ministry of Agriculture and Forestry, in I929 and I930. First, we can consider the explanatory variables relevant to the number of family members. It is notable that the coefficient on the proportion of female family members aged 15 and over, given in the third row, is positive and statistically significant. An increase in the supply of female labour within a household thus seems to result in a greater number of housework hours in that household. This finding allows us to assume the existence of strategic labour allocation behaviour in the household, with the female members being disproportionally allocated to housework. In other words, female household members are strategically important to any increase in housework, as suggested in the previous part of this section.

Second, we can confirm that household expenses influenced housework hours by noticing the positive correlation between per capita household expenses and housework hours, as shown in the fourth row of the table. On the other hand, the income level of the household, expressed by the estimated hourly income per working member of the family, does not positively or significantly correlate with housework hours. These findings imply that household expenses directly influence the number of housework hours, whereas the income level of the household is irrelevant. If expenses are treated as a proxy for the acquisition of goods, it may be suggested that there is a complementary rather than a substitutive relationship between consuming goods and doing housework.

Thus, the analysis of this data set reveals that the demand for housework was influenced by the amount of household expenditure, which in turn corresponded to the level of goods consumption. On the other hand, the number of female workers determined the level of housework supplied. In sum, the number of housework hours supplied per household depended on the level of goods consumption and the endowment of family 
labour in each household. This result suggests that there was a complementary relationship between goods and housework in the context of consumption, offering an image of housework inconsistent with the influential interpretation of Jan de Vries, who assumes a change over time from goods-intensive consumption to service-intensive (houseworkintensive) consumption. ${ }^{\text {II }}$ In contrast, it seems that the consumption of goods in Japan was more closely related to housework, even in peasant households, and well before the emergence of the breadwinner households.

This discrepancy might suggest the possible hypothesis that housework was more significant for Japan's peasant households than for households in Western Europe during the eighteenth and nineteenth centuries, which committed their household members to external labour markets to earn income at the expense of housework. In other words, housework might matter more for enhancing the utilities of members of Japan's peasant households, whereas purchasing goods and services mattered more in Western Europe. If so, housework, along with agricultural and industrial work, should be explicitly counted as one of the factors that determined the labour supply behaviour of Japan's peasants.

Based on these observations, let us consider the logic of the labour supply of peasant households. Although an inconsistency between the required agricultural work and the composition of family members might generate slack labour in a farming household, this slack did not necessarily match the volume of full-time work done by a single person. The seasonal fluctuation of labour demand also prevented the household from generating an idle workforce constantly throughout the seasons. The demand for housework should also be taken into account, since the consumption of goods to enhance utility must have been complemented by labour input with regard to housework. Thus, housework was not regarded as work only performed in the residual hours after paid work was complete but rather required the allocation of time in competition with other labour demands. Under these constraints, female members arranged their time to fulfil their complicated labour demands by engaging in multiple tasks within the household. Thus, Japan's peasant households handled multiple production and re-production tasks through the strategic allocation of family labour, complemented occasionally by only a small number of employees.

As was seen in the case of peasant-weavers, engaging in non-agricultural work as a sideline business is a straightforward illustration of the features of this strategic labour allocation behaviour. The flexible nature of this engagement in terms of working hours and the location was well suited to female workers in peasant households, who were indispensably engaged in multiple tasks, including housework. In other words, the deployment of a dispersed production system contributed to maintaining the workings of peasant households by delivering non-agricultural employment opportunities to households to utilize the slack time that was fragmented among its members and working hours.

This understanding is helpful in considering specific labour supply behaviours of peasant households. A well-known contemporary survey of working conditions investigated by the Ministry of Agriculture and Commerce, Shokkō Jijō 職工事情 (The Circumstances of Factory Workers), reported that "It is more beneficial for local women to weave fabrics 
according to a piece rate at home than to work for a factory that binds them for a long period of time" (I), "In addition to that, in general, female workers at weaving factories are looked down upon in villages" (2). ${ }^{12}$ Statement (I) is consistent with the above discussion, confirming the preference for working within a household because of the favourable working conditions. It is noteworthy that statement (2) described differences in social evaluations, suggesting a lower status for working in a factory. This statement reflected the capacity of the farming households supplying labour to the labour market. Although the suppliers of peasant-weavers included peasants running their own lands as well as landless tenants, workers in weaving factories were said, in the above-mentioned survey, to have been limited to the daughters of financially-pressed households. In fact, the heavy dependence of modern textile factories, such as cotton spinning mills and silk reeling workshops, on low-income petty farming households has been revealed through ample examples in leading scholarly studies. ${ }^{13}$ Thus, putting non-successor sons aside, the first priority for peasant households was bringing job opportunities into those households. Only those who could not afford to bring opportunities into their households released family members to the outside market. The rationale for leading factories in textile industries to recruit workers from remote areas at substantial cost rested on this point. The adequate sources of low-cost labour willing to release their household members to factories were geographically dispersed according to the diffusion of petty peasant households. ${ }^{\mathrm{I}} 4$

Thus, Japan's peasant households were restrictive in committing to the external labour market even though they were neither self-sufficient nor non-sensitive to the market as a whole. Although the intentions and motives behind this specific behaviour can be attributed to the institutional context, that is, the ie system, which urged peasant households to take priority in maintaining their arable lands, as can the rationale for handling multiple tasks within a household, the question of why these behaviours could have been sustainable under the circumstances of the marketization of the economy is worth investigating further. The last section touches on this issue in light of capital accumulation in the rural society.

\section{THE ROLE OF FINANCE IN RURAL SOCIETY}

As mentioned in the previous section, the strength of a peasant household rested on mobilizing its family labour to multiple tasks, including those other than agricultural work. However, the non-agrarian industry followed its own logic to achieve efficiency in producing and selling products. In order to combine these two different spheres, the peasant household and the industry-related market, a mediator was indispensable. In this section, we observe the case of the rural weaving industry in Iruma to exemplify the functions of mediators, such as local merchants and putters-out (putting-out masters or clothiers), and, specifically, their roles in terms of finance, and show the importance of the accumulation of capital in the rural society.

\footnotetext{
I2 Cited from Nōshōmushō I903, p. I78.

I3 Ishii I972; Hunter 2003.

I4 Saitō I998.
} 
First, we will see the role of local merchants during the transformational period of the mid-nineteenth century. ${ }^{\mathrm{I} 5}$ It was soon after the opening of ports in I859 that imported cotton yarn was introduced as a new material for weaving in this district. The stimulus for this introduction is said to have been the return of a cloth dealer of this district, Shōdaya Kyūbei 正田屋久兵衛, from Yokohama, a treaty port, with some cotton yarn that he had purchased. In the I870s, at the latest, more than a few merchants in Iruma district traded imported cotton yarn, including Takizawa Benkichi, one of the leading merchants of this district.

Table ro is a sort of balance sheet of Takizawa's commercial activities in I885. The merchants' names shown here, such as Kakinuma 柿沼, Chōjiya 丁子屋, Nakasō 中惣, and Maekawa 前川, were prominent cotton yarn importers in Yokohama and wholesalers in Tokyo, and they suggest that Takizawa was directly laying in new stock from merchants in the distribution centres by cash or even with the provision of advances. At the same time, payments from the purchasers, namely the producers of cloth in the villages, were postponed for a given period, which is expressed in the category of Tokorozawa chō 帳 literally "notebook", and others. These were the aggregation of small credits to inhabitants by their residential areas, namely Tokorozawa 所沢, Ōme 青梅, Irumagawa 入間川, and Hannō 飯能 regions, which were supposedly purchasers of imported yarns. ${ }^{\mathrm{I} 6}$ The cotton yarn merchant in the district, therefore, made it possible for weavers to adopt foreign yarn, which was less expensive, and in a sense qualitatively superior, which was imperative for their survival. In addition, the existence of kenkin 券金, literally "ticket money", in the asset side of Table Io is noteworthy as it is supposed to indicate promissory notes issued by cloth merchants in local distributing centres. The acceptance of promissory notes as a means of payment must have made it easier for the weavers to purchase yarn, since it prevented weavers from having to wait until the due date to obtain the funds for these purchases. Thus, we can observe the formation of a circulation system of promissory notes.

Figure 2 conceptualizes the circulation of promissory notes from the I86os to I870s, taken from the transaction records of a cloth dealer, the Hosobuchi 細㴊 family, who inhabited a village in Iruma district. The circulation began with the issuing of notes by cloth merchants in Hachiōji 八王子, one of the distributing centres of products manufactured in the surrounding area. The notes were accepted by the Hosobuchi family, who collected cotton cloth woven by weavers, who were usually embedded in peasant households. If the Hosobuchi family held the notes until the due dates, the family was to be regarded as a creditor because its payment for collecting cloth was made on the day of the purchase. Essentially, Hosobuchi often paid weavers in notes that directed the Tanakaya Hikobei 田中屋彦兵衛 to hand over cash in exchange for the notes if they were brought in to his office, and Hosobuchi used the promissory notes accepted from Hachiōji merchants to compensate for Tanakaya's payment. In this regard, the true creditor who enabled Hosobuchi to accept promissory notes was Tanakaya Hikobei. In this case, Tanakaya acted as a genuine financier since he was not engaged in the transactions of materials or woven products. In contrast, Figure 3 conceptualizes the case based on the information

I5 The historical facts on the roles of local merchants are obtained from Tanimoto I998, ch. 2.

I6 This supposition is confirmed by documents from a purchaser, Motohashi Michisuke, who postponed the payment for purchased yarn and constantly bore liabilities to a yarn merchant. 
about "ticket money" shown in Table ro. In this figure, the yarn merchant served as an anchor by accepting promissory notes as a means of payment and substituting for the role of financier in this circle. On the other hand, Table so indicates that the financial basis of this yarn merchant, Takizawa, rested at least partly on loans given by local banks together with its own equity, which matched the difference in the values of assets and liabilities. In other words, the capital accumulated in various forms within the region played a significant role in establishing the smooth distribution of imported yarns indispensable for making the weaving industry competitive and sustainable.

Secondly, even after the establishment of the putting-out system in Iruma from the I89os onwards, the role of the mediator between peasant households and the product market was vital. ${ }^{17}$ As we already saw in Figure I, there was a distinctive discrepancy in the seasonal fluctuations of the supply and demand of weaving labour, since the former and the latter were determined independently by different factors, agricultural seasonality, and the preferences of the product market. In order to utilize the abundant slack labour in the winter for manufacturing products most saleable in autumn, the clothiers, namely putters-out, had to keep stocks for more than half a year. In fact, Table I I shows that relatively large stocks of finished goods existed in the first half of the year. From this situation emerged the requirement of a relatively large level of running capital. Since the financial demand seemed to be covered mainly by its own capital, according to Table I I, it was this accumulation of capital by clothiers themselves that helped to achieve the initial capital requirements, presumably by an owner farming two to three hectares of arable land and dealing cotton cloth as a local dealer in the I870s and the I880s. In the course of time, along with an increase in production, funds from a local bank in the form of liabilities or discounts on promissory notes became significant. In fact, there emerged a movement to establish local banks in Tokorozawa, a developing prominent distributing centre in this region led by traders related to the weaving industry. The formation of financial institutions based on these individual accumulations enabled the region to overcome financial problems and maintain the competitiveness of this industry.

\section{CONCLUSION}

Under the expansion of arable land and growth in population, independent peasant households proliferated in Japan in the seventeenth century. Around the turn of the eighteenth century, when the reclaimable frontier became exhausted and the growth in arable land almost ceased, an important institutional change, the diffusion of the single inheritance system, took place. This change resulted in the fixture of the stem-family system in peasant households. Combined with the idea of ancestor worship, peasant households transformed into entities called ie, which owned family properties and bore the responsibility of conveying their properties to the next generation. Under this constraint, peasant households prioritized their own farming and mobilized family members into agricultural work. The labour-intensive nature of contemporary agricultural techniques, which were developed to enhance land productivity, were well suited to family farming, since the family workers had incentives to invest their labour intensively into their family businesses. 
The development of the market economy also contributed to maintaining and activating the peasant society. Not only did the commercialization of agricultural production widen the opportunities for profit-making, but the distribution of fertilizer made from fish, specifically sardines and herring, also overcame the resource constraint associated with the previous forms of fertilizer, compost and manure, which were made from land using materials such as grass. ${ }^{18}$ On the other hand, the function of the labour market was strongly influenced by the strategy of peasant households to pursue the optimal utilization of slack labour generated by the seasonally fluctuating labour demand from agriculture. The strong housework requirements also competed with other labour demands. Under these constraints, peasant households tended to deliver non-agricultural employment opportunities to their members, trying to utilize the slack time that was fragmented among these family members. Although the transaction of labour was certainly conducted under the market mechanism, there were nevertheless some barriers to mobilizing family workers outside the household.

These barriers were supported by region-based industrial development. In fact, the development of the putting-out system in the weaving district enabled the provision of employment opportunities, specifically piece-rate weaving work, which mostly fit the requirements of peasant households. Rural-based capital accumulation together with the workings of the regional financial markets contributed to maintaining particular peasant household behaviours by supporting region-based industrial development. Thus, it was not the lack of a factor market but its unique functions that resulted in maintaining and even activating peasant society in industrializing Japan. It is inappropriate to regard the peasant household as either a remnant of the subsistence economy or a pure player in the market economy. Considering the particular behaviour of the peasant household in comparative perspective is key to a better understanding of the features of Japan's path of economic and social development from the early modern to the modern period. ${ }^{\text {I9 }}$

\section{REFERENCES}

de Vries 2008

de Vries, Jan. The Industrious Revolution: Consumer Behaviour and the Household Economy, I650 to the Present. Cambridge: Cambridge University Press, 2008.

Hayami, Saitō, and Toby eds. 2004

Hayami, Akira, Osamu Saitō and Ronald P. Toby eds. Economic History of Modern Japan, Vol. I: Emergence of Economic Society in Japan I600-I859, Oxford: Oxford University Press, 2004.

Hunter 2003

Hunter, Janet. Women and the Labour Market in Japan's Industrialising Economy: The Textile Industry before the Pacific War. Abingdon: RoutledgeCurzon, 2003.

Ishii 1972

Ishii, Kanji 石井 寛治. Nihon Sanshigyōshi Bunseki: Nihon Sangyō Kakumei Kenkyū Jyoron 日本虫系業史分析一日 本産業革命研究序論 (The Analysis of Japanese Silk Reeling and Cocoon Breeding Industry: The Introduction of the Japanese Industrial Revolution). Tokyo: Tōkyō Daigaku Shuppankai, I972.

Miwa and Hara 2007

I8 The role of fish fertilizer in the context of resource constraints is discussed, albeit briefly, in Sawai and Tanimoto 20I6, ch. I.

I9 Tanimoto 2013 tries to widen the perspective of the discussion of peasant society by focusing on its urban successors, self-employed small businesses from the ig2os onwards. 
Miwa, Ryōichi 三和 良一 and Akira Hara 原 朗. Kingendai Nihonkeizaishi Yōran 近現代日本経済史要覧 (The Handbook of Modern and Contemporary Economic History of Japan). Tokyo: Tōkyō Daigaku Shuppankai, 2007. Miyajima 1994

Miyajima, Hiroshi 宮嶋 博史. “Higashiajia shōnōshakai no keisei 東アジア小農社会の形成 (The Formation of East Asian Peasant Society).” In Ajia kara Kangaeru 6 Chōki Shakaihendōアジアから考える 6 長期社会変動 (Thinking from Asia 6 Long-term Social Change), ed. Mizoguchi Yūzō 溝口 雄三 et al. Tokyo: Tōkyō Daigaku Shuppankai, 1994 .

Mokyr I990

Mokyr, Joel. The Lever of Riches: Technological Creativity and Economic Progress. Oxford: Oxford University Press, I990. Nōshōmushō I903

Nōshōmushō 農商務省 eds. (I903/r998). Shokkō Jijōo 職工事情 (The Circumstances of Factory Workers), rpt. Tokyo: Iwanamishoten, I998 (I903).

Pomeranz 2000

Pomeranz, Kenneth. The Great Divergence: Europe, China and the Making of the Modern World Economy. Princeton University Press, 2000.

Saitō 2008

Saitō, Osamu 斎藤 修. Hikaku Keizai hatten-ron: Rekishiteki Apurouchi 比較経済発展論一歴史的アプローチ (The Comparative Economic Development: Historical Approach). Tokyo: Iwanamishoten, 2008.

Saitō 1998

Saitō, Osamu 斎藤 修. Chingin to Rōdō to Seikatsusuijun: Nihonkeizaishi ni okeru I 8-20 seiki 賃金と労働と生活水 準一日本経済史における I8-20 世紀 (Wage, Labour and Standard of Living: The 18th to 20th Century in Japanese Economic History). Tokyo: Iwanamishoten, 1998.

Sawai and Tanimoto 2016

Sawai, Minoru 沢井実 and Masayuki Tanimoto 谷本 雅之. Nihon Keizaishi: Kinsei kara Gendai made 日本経済 史一近世から現代まで (The Economic History of Japan: From the Early Modern Era to the Present). Tokyo: Yūhikaku, 2016.

Tanimoto 2016

Tanimoto, Masayuki 谷本 雅之. "Nichijōseikatsu ni okeru kajirōdō no yakuwari: mōhitotsu no shōhishi to shite 日常生活における家事労働の役割—もう一つの消費史として (The Role of Housework in Everyday Life: Another Aspect of Consumption in Modern Japan)." In Rekishi nonakano Shōhisha: Nihon ni okeru Shōhi to Kurashi I850-2000 歴史の中の消費者一日本における消費と暮らし I850-2000 (The Historical Consumer: Consumption and Everyday Life in Japan, I850-2000), eds. Penelope Francks ペネロピ・フラン クス and Janet Hunter ジャネット・ハンター. Tokyo: Hosei Daigaku Shuppankyoku, 2016.

Tanimoto 2013

Tanimoto, Masayuki. "From Peasant Economy to Urban Agglomeration: the Transformation of 'Labour-Intensive Industrialization' in Modern Japan.” In Labour-intensive Industrialization in Global History, eds. Gareth Austin and Kaoru Sugihara. Abingdon: Routledge, 2013.

Tanimoto 2012

Tanimoto, Masayuki. "The Role of Housework in Everyday Life: Another Aspect of Consumption in Modern Japan." In The Historical Consumer: Consumption and Everyday Life in Japan, I850-2000, eds. Penelope Francks and Janet Hunter. New York: Palgrave Macmillan, 2012.

Tanimoto 2009

Tanimoto, Masayuki. "Cotton and the Peasant Economy: Foreign Fibre in Early Modern Japan." In The Spinning World: A Global History of Cotton Textile I200-I850, eds. Giorgio Riello and Prasannan Parthasarathi. Oxford: Oxford University Press, 2009.

Tanimoto 2006a

Tanimoto, Masayuki. “The Role of Tradition in Japan's Industrialization: Another Path to Industrialization.” in The Role of Tradition in Japan's Industrialization, ed. Masayuki Tanimoto. Oxford: Oxford University Press, 2006.

Tanimoto 2006b

Tanimoto, Masayuki 谷本 雅之. "Shōnō shakai ni okeru nōgyō koyōrōdō: kinsei Kinai nōson no ichi, ni no jirei 小農社会における農業雇用労働一近世畿内農村の一、二の事例 (Agricultural Labourers in the 'Peasant Society': Case Studies of Farming Villages in Early Modern Kinai)." Keizai-Shirin 経済志林 (The Hosei University Economic Review) 73:4 (2006), pp. 235-52.

Tanimoto 2003

Tanimoto, Masayuki 谷本 雅之. “Kindai Nihon no josei rōdō to 'shōkeiei” 近代日本の女性労働と小経営 (Women's Labour and the Small Business in Modern Japan). In Nihon Kindai Kokka no Seiritsu to Jendaa 日 
本近代国家の成立とジェンダー (Gender and the Formation of Modern State in Japan), ed. Ujiie Mikito 氏家 幹人 et al. Tokyo: Kashiwa Shobō, 2003.

Tanimoto I998

Tanimoto, Masayuki 谷本 雅之. Nihon ni okeru Zairaiteki Keizaihatten to Orimonogyō: Shijōkeisei to Kazokukeizai 日本における在来的経済発展と織物業一市場形成と家族経済 (The Indigenous Economic Development and the Weaving Industry: Market Formation and Household Economy). Nagoya: Nagoya Daigaku Shuppankai, I998.

Umemura et al. eds. I988

Umemura, Mataji 梅村 又次 et al. eds. Chōkikeizaitōkei 2 Rōdōryoku 長期経済統計2 労働力 (Estimate of Long-term Economic Statistics of Japan since I868, Vol.2, Manpower). Tokyo: Tōyō Keizaishinpōsha, I988.

\section{APPENDIX}

Figure r. Seasonal fluctuation of order, sales and piece rate in the weaving industry (Case of the Takizawa family, I897, Iruma district)

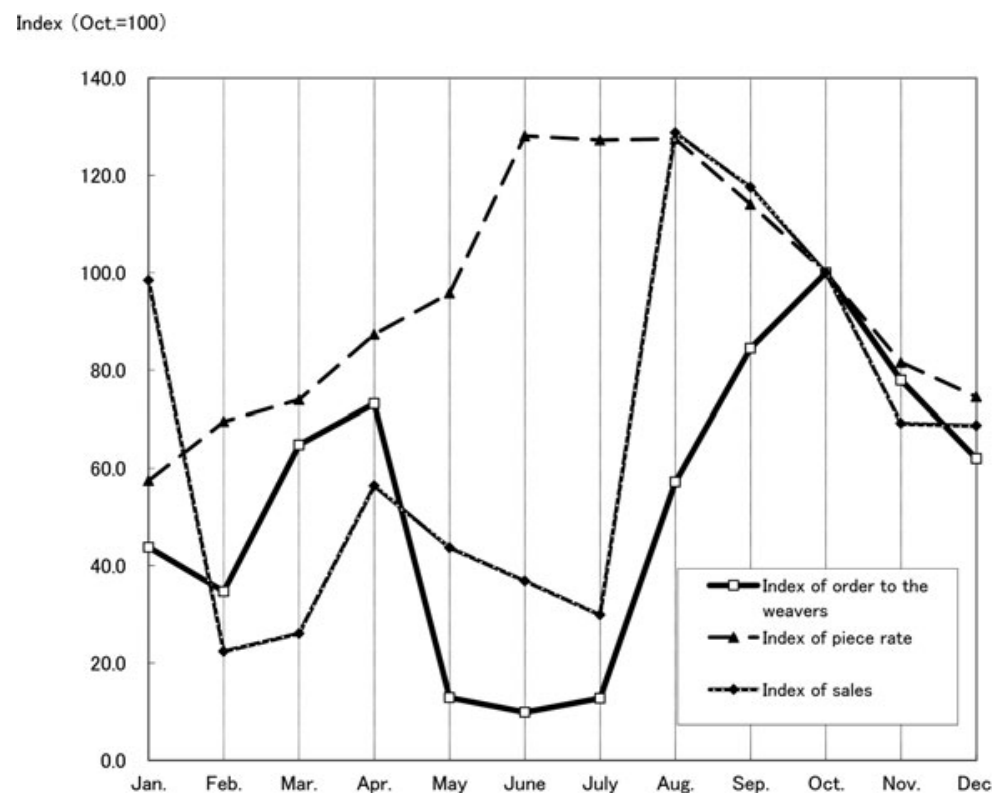

Source: Tanimoto 2006a, Figure I-I.

Figure 2. Circulation of promissory notes (I)
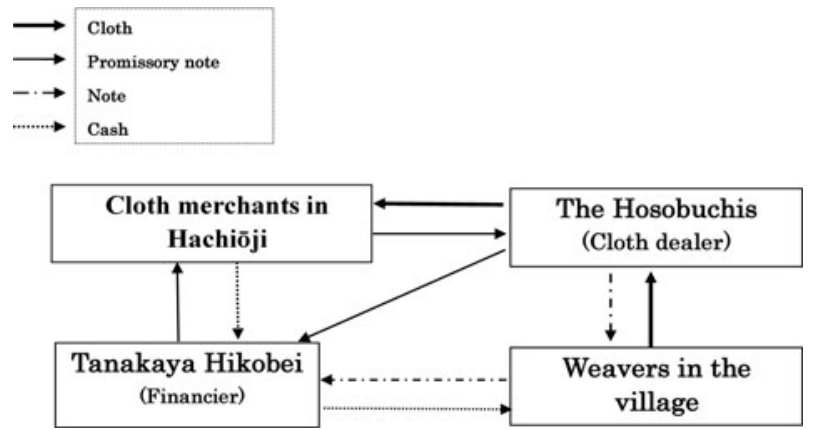

Source: Tanimoto I998, ch. 2. 
Figure 3. Circulation of promissory notes (II)
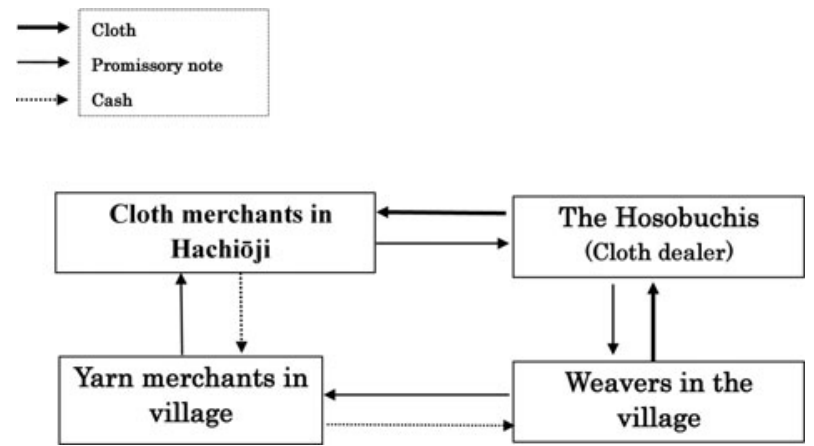

Source: Tanimoto I998, ch. 2.

Table r. Number of farming households (unit: thousand)

\begin{tabular}{lr}
\hline I 880 & 5,499 \\
I 890 & 5,448 \\
I900 & 5,502 \\
I9I0 & 5,518 \\
I920 & 5,564 \\
I930 & 5,614 \\
I940 & 5,484 \\
\hline
\end{tabular}

Source: Umemura et al. I988, pp. 218-19.

Table 2. Number of farming households by farm acreage (proportion)

$(\%)$

\begin{tabular}{lccc}
\cline { 2 - 4 } & & Proportion & \\
\cline { 2 - 4 } & Less than 0.8 hectares & $0.8-\mathrm{I} .5$ hectares & I.5 hectares and more \\
\hline I888a & 55.0 & 30.0 & I 5.0 \\
I $888 \mathrm{~b}$ & 56.6 & 29.4 & I 4.I \\
I908 & 58.2 & 25.7 & I6.I \\
\hline
\end{tabular}

Source: Miwa and Hara eds. 2007, table I-20 (a).

Note: a refers to the estimation by Wataya Takeo, b refers to the estimation based on Nöjichōsahyō. 
Table 3. Agricultural day labour in the Asada family, 1783

\begin{tabular}{|c|c|c|c|c|c|c|c|c|c|c|c|c|c|c|c|}
\hline \multirow[b]{2}{*}{ Place } & \multirow[b]{2}{*}{ Name } & \multirow[b]{2}{*}{ Sex } & \multicolumn{13}{|c|}{ (Day) } \\
\hline & & & Jan. & Feb. & March & April & May & June & July & Aug. & Sep. & Oct. & Nov. & Dec. & Total \\
\hline Ueno & Gohei & M & I4 & 20 & I8 & 20 & I5 & I6 & I7 & I5 & I5 & I9 & I9 & I6 & 204 \\
\hline Kona & Seiishichi & M & 4 & 7 & 3 & I & 5 & 7 & 4 & 6 & 5 & 6 & 4 & 9 & 6I \\
\hline Mito & Kyūshirō & $\mathrm{M}$ & 3 & 5 & 6 & IO & 2 & 3 & I & & 3 & 4 & & 2 & 39 \\
\hline Ueno & Riyo/Shichirobei & $\mathrm{F} / \mathrm{M}$ & I & & I & I & IO & I & & & & 8 & I 2 & I & 35 \\
\hline Nohi & Heisuke & $\mathrm{M}$ & & & & & 5 & 4 & 4 & 8 & 4 & 6 & & & $3 \mathrm{I}$ \\
\hline Kadono & Seishichi & M & & & & 2 & 3 & 4 & IO & & & 2 & 4 & 3 & 28 \\
\hline \multirow[t]{2}{*}{ Iso } & Kiroku & M & 2 & & 3 & & & 2 & I & I & I & 2 & 9 & 6 & 27 \\
\hline & Suki & $\mathrm{F}$ & & & & & & & & & & IO & 6 & & I 6 \\
\hline Iso & Chukichi & M & & & 9 & 2 & 2 & 2 & & & & & & & I5 \\
\hline Kona & Bunshichi & M & I & I & 3 & 3 & I & 2 & I & & & & 2 & & I4 \\
\hline Iso & Heihachi & M & & & & & 2 & 2 & 3 & & & & 5 & & I 2 \\
\hline \multirow[t]{2}{*}{ Hayashi } & Sadashichi & M & & & & & & I & 3 & 8 & & & & & I 2 \\
\hline & Kiri & $\mathrm{F}$ & & & & & 9 & & & & & & & & 9 \\
\hline Iso & Ihei & $\mathrm{M}$ & & & 2 & & & & 3 & & I & I & & I & 8 \\
\hline Nohi & Isuke & M & & I & I & I & I & I & I & & & I & & & 7 \\
\hline \multirow[t]{2}{*}{ Kona } & Shinpachi & M & & & & & I & & & 2 & 3 & & & I & 7 \\
\hline & Yahei & M & & & & & & & & & 4 & I & & & 5 \\
\hline Mitono & Kahei & M & & & & & 3 & I & & & & I & & & 5 \\
\hline Tono & Shōzaburō & M & & & & & & 2 & I & & & & 2 & & 5 \\
\hline Mito & Risu & $\mathrm{F}$ & & & & & & & 3 & & & & & & 3 \\
\hline Iso & Kishichirō & M & & & & & I & & & & & I & & & 2 \\
\hline Tono & Rihachi & M & & & & & & & & & & I & & & I \\
\hline Nohi & Jinpachi & $\mathrm{M}$ & & & & & & & & & & I & & & I \\
\hline Fushimi & Yohei & $\mathrm{M}$ & & & & & & & & & I & & & & I \\
\hline Sumi & Jirobei & $\mathrm{M}$ & & & & & & & & & & I & & & I \\
\hline Mitono & Sadashichi & M & & I & & & & & & & & & & & I \\
\hline Mito & Shōkurō & M & & & & & & & & & & I & & & I \\
\hline \multirow[t]{2}{*}{ Tono } & Yasuke & $\mathrm{M}$ & & & & & & & & & & I & & & I \\
\hline & Total & & 25 & 35 & 46 & 40 & 60 & 48 & 52 & 40 & 37 & 67 & 63 & 39 & 552 \\
\hline
\end{tabular}

Source: Tanimoto 2006b, Table 3. 
Table 4. Working day of Gohei at the Asadas (I783)

\begin{tabular}{|c|c|c|}
\hline & Day at work & Paid in daily wage \\
\hline $\begin{array}{l}\text { I/Oct. } \\
\text { 2/Oct. } \\
\text { 3/Oct. } \\
\text { 4/Oct. } \\
\text { 5/Oct. } \\
\text { 6/Oct. } \\
\text { 7/Oct. } \\
\text { 8/Oct. } \\
\text { 9/Oct. } \\
\text { I0/Oct. } \\
\text { I I/Oct. } \\
\text { I2/Oct. } \\
\text { I3/Oct. } \\
\text { I4/Oct. } \\
\text { I 5/Oct. } \\
\text { I6/Oct. } \\
\text { I7/Oct. } \\
\text { I 8/Oct. } \\
\text { I9/Oct. } \\
\text { 20/Oct. } \\
\text { 2 I/Oct. } \\
\text { 22/Oct. } \\
\text { 23/Oct. } \\
\text { 24/Oct. } \\
\text { 25/Oct. } \\
\text { 26/Oct. } \\
\text { 27/Oct. } \\
\text { 28/Oct. } \\
\text { 29/Oct. } \\
\text { 30/Oct. }\end{array}$ & $\begin{array}{l}0 \\
0 \\
0 \\
0 \\
0 \\
0 \\
0\end{array}$ & \\
\hline
\end{tabular}

Source: Tanimoto 2006b, Table 4. 
Table 5. Occupational situation of peasant household in Udaōtsu village, Izumi district, I843

\begin{tabular}{|c|c|c|c|c|c|c|c|c|c|c|c|}
\hline \multirow{3}{*}{$\begin{array}{l}\text { Per capita area of cultivation (Family } \\
\text { member; age } 15-60+\text { long-term } \\
\text { employee) } \\
\text { (hectare) }\end{array}$} & \multirow[t]{3}{*}{$\begin{array}{l}\text { Number of } \\
\text { households }\end{array}$} & \multirow{3}{*}{$\begin{array}{l}\text { Proportion of } \\
\text { tenanted land } \\
\\
\text { (\%) }\end{array}$} & \multirow{3}{*}{$\begin{array}{l}\text { Number of household } \\
\text { members (age I5-60) } \\
\text { Average } \\
\text { (person) }\end{array}$} & \multirow[b]{3}{*}{$\begin{array}{l}\text { One person } \\
\text { household } \\
\text { (\%) }\end{array}$} & \multicolumn{7}{|c|}{$\begin{array}{l}\text { Works other than cultivation of their own run lands } \\
\text { (Number of households allocating members to the } \\
\text { work/Total number of households in each stratum) }\end{array}$} \\
\hline & & & & & \multicolumn{2}{|c|}{$\begin{array}{l}\text { Yearly } \\
\text { contracted } \\
\text { work } \\
\text { (living in) }\end{array}$} & \multicolumn{5}{|c|}{ Side line job } \\
\hline & & & & & $\begin{array}{l}\text { Male } \\
(\%)\end{array}$ & $\begin{array}{l}\text { Female } \\
\text { (\%) }\end{array}$ & $\begin{array}{l}\text { Total } \\
(\%)\end{array}$ & $\begin{array}{l}\text { Spinning } \\
\text { (\%) }\end{array}$ & $\begin{array}{l}\text { Weaving } \\
\text { (\%) }\end{array}$ & $\begin{array}{l}\text { Other } \\
\text { businesses } \\
\text { (\%) }\end{array}$ & $\begin{array}{l}\text { Daily } \\
\text { works } \\
(\%)\end{array}$ \\
\hline 4.0-- & I & 62.5 & I.OO & IOO.O & & & & & & & \\
\hline $3 \cdot 5^{--}$ & I & 50.0 & 2.00 & & & & & & & & \\
\hline 3.0-- & I & 46.2 & 4.00 & & & & & & & & \\
\hline $2.5^{--}$ & 4 & 56.5 & 2.50 & & & & 50.0 & 25.0 & 25.0 & & \\
\hline $2.0--$ & I6 & 46.7 & 2.69 & I 2.5 & & & 50.0 & 37.5 & 6.3 & 6.3 & 6.3 \\
\hline I. $5^{--}$ & $3 \mathrm{I}$ & 54.6 & 2.52 & I6.I & & & 83.9 & 67.7 & I 2.9 & I 2.9 & 32.3 \\
\hline I.O-- & 44 & 62.6 & 3.20 & 6.8 & 6.8 & 6.8 & 90.9 & 72.7 & I 5.9 & I 5.9 & 36.4 \\
\hline $0.5^{--}$ & 54 & 87.5 & 2.72 & II.I & $9 \cdot 3$ & I.9 & 94.4 & 64.8 & $33 \cdot 3$ & I 8.5 & 44.4 \\
\hline less than 0.5 & 37 & 9г.8 & 3.14 & & $35 . \mathrm{I}$ & I 3.5 & 91.9 & 56.8 & 32.4 & I 8.9 & $35 . \mathrm{I}$ \\
\hline No cultivation & 90 & & 2.00 & 38.6 & 34.4 & I5.6 & 74.4 & 58.9 & 25.6 & I 6.7 & IO.O \\
\hline Total & 279 & 63.9 & 2.59 & I 8.6 & I 8.6 & 8.2 & 82.1 & 60.6 & 23.7 & I5.8 & 26.2 \\
\hline
\end{tabular}

Source: Tanimoto I998, Table 4-4. 
Table 6. Agrarian and cotton production in peasant households in Kitano village, Iruma district, c. I875

\begin{tabular}{|c|c|c|c|c|}
\hline \multicolumn{2}{|c|}{ Households producing grains* } & \multicolumn{3}{|c|}{ Households producing striped cotton cloth } \\
\hline $\begin{array}{l}\text { Value of production of } \\
\text { grains per household } \\
\text { (in yen) }\end{array}$ & $\begin{array}{c}\text { Number of } \\
\text { households: A }\end{array}$ & $\begin{array}{c}\text { Number of } \\
\text { households: } B\end{array}$ & $\begin{array}{l}\text { Turn rate of } \\
\text { household } \\
\text { B/A (\%) }\end{array}$ & $\begin{array}{l}\text { Value of production of } \\
\text { cotton cloth per household } \\
\text { (in yen) }\end{array}$ \\
\hline No production & 2 & I & 50.0 & II 2.5 \\
\hline Less than IO & 43 & 6 & I 4.0 & 36.1 \\
\hline IO-I9 & $5 \mathrm{I}$ & 22 & 43.I & 57.5 \\
\hline $20-29$ & 40 & I9 & 47.5 & 35.3 \\
\hline 30-39 & 27 & I4 & $5 \mathrm{I} .9$ & I6.I \\
\hline $40-49$ & I7 & 6 & $35 \cdot 3$ & 62.3 \\
\hline 50-99 & 35 & I6 & 42.9 & $3 \mathrm{I} .4$ \\
\hline More than Ioo & 5 & 2 & 40.0 & 77.6 \\
\hline Total & 220 & 85 & 38.6 & 4I.I \\
\hline
\end{tabular}

Source: Kitano-mura Bussan Torishirabe Kakiage (Archives of the Iwaoka Family).

Note: *Involves the production of barley, rice, wheat, millet, beans and potatoes, but excludes the cultivation of tea and breeding silk cocoons.

Table 7. The apportion of labour among a peasant's household (Igor, in Senpoku-gun, southern part of Osaka prefecture)

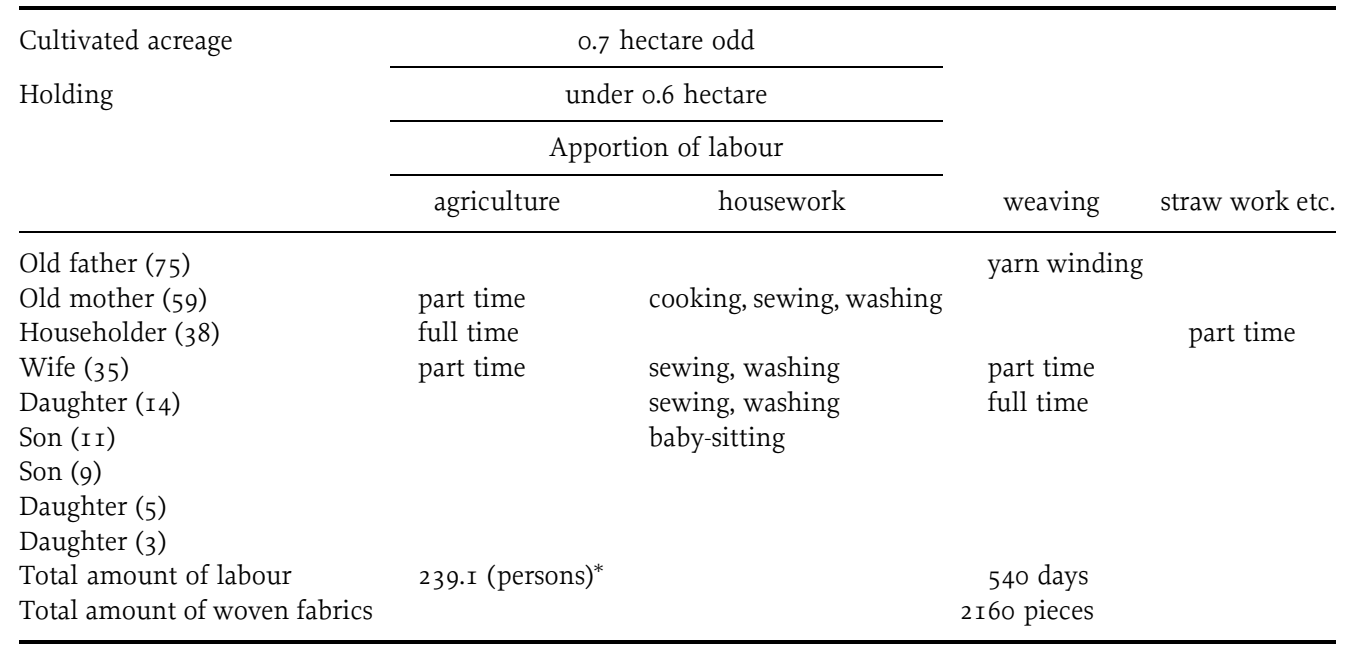

Source: Tanimoto 2006a, Table I-4.

Notes: ${ }^{*}$ One day's work by one person $=$ one person. The number in parenthesis is the person's age. 
Table 8. Allocation of labour within a farming household in Tottori prefecture, I9I8

\begin{tabular}{|c|c|c|c|c|c|c|c|}
\hline \multirow[t]{2}{*}{ Position in the family } & \multirow[t]{2}{*}{ Age } & \multirow[t]{2}{*}{ Total } & \multicolumn{3}{|c|}{ Agriculture and industry } & \multirow[t]{2}{*}{ Housework } & \multirow[t]{2}{*}{ Others } \\
\hline & & & Total & Agricultural work & Others & & \\
\hline \multicolumn{8}{|c|}{ Working hours per year } \\
\hline Household head & 44 & 3,156 & 2,564 & I,6I8 & 946 & 437 & I 55 \\
\hline Wife & 40 & 3,278 & 2,456 & I,006 & $\mathrm{I}, 450$ & 822 & \\
\hline Father & $7 \mathrm{I}$ & $\mathrm{I}, 982$ & $\mathrm{I}, 672$ & $\mathrm{I}, \mathrm{I} 4 \mathrm{O}$ & 532 & 275 & 35 \\
\hline Mother & 67 & $3,92 \mathrm{I}$ & 803 & 265 & 538 & 3,I I 8 & \\
\hline Daughter & I8 & 3,399 & 2,082 & I,I60 & 922 & $\mathrm{I}, 3 \mathrm{I} 7$ & \\
\hline Daughter & I5 & $\mathrm{I}, \mathrm{O} 2 \mathrm{O}$ & I35 & 80 & 55 & 885 & \\
\hline Son & 9 & & & & & & \\
\hline Son & 2 & & & & & & I90 \\
\hline Total & & I6,756 & 9,7 I 2 & 5,269 & 4,443 & 6,854 & 380 \\
\hline
\end{tabular}

Source: Tanimoto 20I2, Table 2-I.

Table 9. The determinant of housework hours: the results of multiple regression analysis, OLS (dependent variable: yearly housework hours per household)

Independent variables

I929/I930

No. of family members

$375.7 * * *$

No. of family members under 8

45.0

No. of female family members I 5 and over

I388.9*

743.2

348I.4***

869.8

Expenses per family members in square root

$3.4 * * *$

0.8

Income per working hours

$-672.0$

I076.6

I929 dummy

I00.2

203.8

Owner-tenant dummy

-I 22.0

Owner dummy

238.3

I 53.5

249.7

y axis-intercept

- I I 23.9

570.3

No. of samples

436

$\mathrm{R}^{2}$ (Adjusted)

0.203

Source: Tanimoto 2016, Table 2-5.

Notes: Coefficient in upper line and standard error in bottom line.

*** Significant at one percent level.

*Significant at ro percent level. 
Table ro. A "balance sheet” of Takizawa Benkichi's cotton yarn dealing business as of March I 885 (unit: yen)

\begin{tabular}{|c|c|c|}
\hline Assets & Items & Liabilities \\
\hline 662 & Surroundings chō & 2,535 \\
\hline I,2 I 6 & Irumagawa chō & 45 \\
\hline \multirow[t]{2}{*}{653} & Ōme chō & 2,850 \\
\hline & Ōme bank & $2, \mathrm{I} 70$ \\
\hline \multirow[t]{2}{*}{4,789} & Tokorozawa chō & 9I9 \\
\hline & Hachiōji bank & IOO \\
\hline $6 \mathrm{I7}$ & Hanno chō & 33 \\
\hline \multirow[t]{2}{*}{ I,234 } & Direction of Tokyo & 5,645 \\
\hline & Ōme bank & 4,529 \\
\hline I 28 & Kakinuma & \\
\hline I58 & Chōjiya & \\
\hline I68 & Nakasō & \\
\hline I & Maekawa & \\
\hline 550 & Extract for rechecking & \\
\hline 2,644 & Tokorozawa stock (yarn) & \\
\hline 442 & Hannō stock (yarn) & \\
\hline 398 & Irumagawa stock (yarn) & \\
\hline 428 & Ōme stock (yarn) & \\
\hline 357 & Inside stock (yarn) & \\
\hline I,9I4 & Ōme kenkin & \\
\hline $\mathrm{I}, 270$ & Tokorozawa kenkin & \\
\hline 265 & Hannō kenkin & \\
\hline Io & Others & 2 \\
\hline I7,453 & Total & I 2,029 \\
\hline
\end{tabular}

Source: Tanimoto I998, Table 2-Io.

Table Ir. A "balance sheet" of Takizawa Kumakichi's business

I 896 Nov.

I897 June

\section{Assets}

Cloth-related assets

Stock of cloths

$\begin{array}{rr}4,6 \mathrm{I} 6 & 4,6 \mathrm{I} 3 \\ 2,23 \mathrm{I} & 4,4 \mathrm{IO} \\ 3,600 & 5,393 \\ 935 & \mathrm{I}, 300 \\ \mathrm{I} 20 & \mathrm{I} 20 \\ 4, \mathrm{I} 00 & \mathrm{I}, 630 \\ \mathrm{I}, \mathrm{I} 05 & \mathrm{I}, 787 \\ & 60 \\ \mathrm{I} 4,475 & \mathrm{I} 4,903\end{array}$

Yarn related assets

Deposit

5,393

Shares

Cash and bills

I 20

Loans

630
787

Others

I 4,475

I 4,903

\section{Liabilities}

Borrowing

Total

Source: Tanimoto I998, Table 6-2I. 